\title{
Technology policy learning and innovation systems life cycle: the Canadian aircraft industry
}

\author{
Majlinda Zhegu \\ Department of Management and Technology, \\ Université du Québec à Montréal, \\ Case Postale 8888, Succursale Centre-ville, \\ Montréal (Québec) H3C 3P8, Canada \\ E-mail: zhegu.majlinda@uqam.ca
}

\begin{abstract}
This study aims to bridge the literature regarding organisational learning and the system of innovation perspective. This paper explores the dynamics of technology policy learning in an innovation systems context. Firstly, the main findings on organisational learning attributes are presented. Secondly, the process of public policy learning is discussed. Finally, a life cycle approach for analysing technology policy learning is presented for the Canadian aerospace industry. By discerning the complimentary factors among differing theoretical perspectives, this paper provides a better understanding of the process and evolution of technological policy.
\end{abstract}

Keywords: aircraft industry; technology policy; organisational learning; aircraft sectoral innovation systems; aircraft national innovation systems; technology policy learning.

Reference to this paper should be made as follows: Zhegu, M. (2013) 'Technology policy learning and innovation systems life cycle: the Canadian aircraft industry', Int. J. Technology and Globalisation, Vol. 7, Nos. 1/2, pp. $23-40$.

Biographical notes: Majlinda Zhegu is a Professor in the Department of Management and Technology at the Université du Québec à Montréal since 2007. In 1997, she obtained her Doctorate in International Economics at the Université de Pau et des Pays de l'Adour (France). In 2007, she obtained her $\mathrm{PhD}$ in Business Management at the Université du Québec à Montréal. Her $\mathrm{PhD}$ thesis was about the co-evolution of aircraft industry and its innovation systems. The management of technology and innovation, organisational learning, technology and innovation diffusion and internationalisation are among her main research interest areas. She has published several papers related to the emergence and growth of aerospace innovation systems.

\section{Introduction}

The success of an innovation system relies on the learning capabilities of its constituents (Lundvall, 2010). The most important elements of innovation systems are dependent on the learning capabilities of individuals, organizations, and regions. However, crucial details of their capacity and ability to learn are lacking [Lundvall et al., (2002), p.224]. In the case of technological policies, the need for an in-depth understanding of learning 
content, processes, and mechanisms is even more compelling. Evidence of successful public policies corroborates the thesis that government's principal role

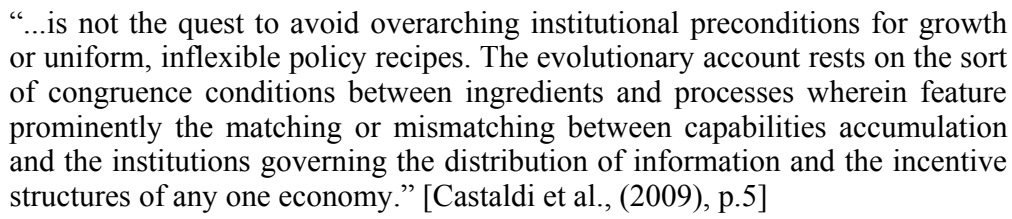

This in turn leads to the question: How technological policy learning evolves within a national innovation system context?

The following section defines the main characteristics of organizational learning. Then, the dynamic nature of technological policy learning is discussed and a framework proposed that considers the technology policy learning in the context of the innovation system life cycle. The empirical research is based in a diachronic analysis of the technological 'catch-up' and 'keep-up' of Canadian technology policies in the aerospace sector.

\section{Organisational learning: definition and attributes}

Learning is a recurrent theme in many theoretical perspectives, but no general theory of organizational learning and no set of best practices have emerged yet. Economics, sociology, political, historical, and management studies offer valuable insights on the premises, contextual factors, sources, types, and levels of organizational learning. In the following session, organizational learning is defined and the attention is drowned to its main salient features.

\subsection{Definition of the organisational learning}

For the purpose of this research, organisational learning is defined as the process of exploring and exploiting internal and external new knowledge aiming to maintain or improve the performance of the organization. This definition emphasizes organizational learning as a sustained phenomenon which generates gradual changes reflected by successful organizational transformation and improved actions through better knowledge and understanding (Fiol and Lyles, 1985; Auluck, 2002).

The competitive advantage of an organization is grounded on the process of generation, capturing, and applying critical new knowledge. This learning process relies on the organizational absorptive capacity, which is the organization's ability to recognize the value of new external knowledge, assimilate it, and apply it to commercial advantage (Cohen and Levinthal, 1989; Zahra and Georges, 2002; Lane et al., 2006). Between organizational learning and organizational absorptive capacity, there is a co-evolutionary relationship (Van den Bosch et al., 2003). Endowed with a superior absorptive capacity, an organization will produce more product or process innovations while enhancing its organizational learning (Cohen and Levinthal, 1989). Therefore, absorptive capacity may be considered as a major predictor and enabler of organizational learning. 


\subsection{Attributes of organisational learning}

Organizational learning is a complex process spanning over several stages. Based on the degree of absorption of new knowledge in an organization's routines, Crossan et al. (1999, p.525) quarter the organizational learning process in the intuiting-interpretingintegrating-institutionalising phases. Other authors extend the organizational learning process by including the organizational memorizing, learning, and unlearning as some other important phases affecting present and future learning (Fiol and Lyles, 1985).

Organization learning relies on an organization's direct experiences as well as on the experiences of others. Empirical research has identified various modes of organizational learning as the learning-by-doing (Arrow, 1962), learning by detection and correction of errors (Argyris, 2005), learning by using (Rosenberg, 1982), learning by interacting (Lundval et al., 2002), learning by searching (Johnson, 1992), or the learning by performance feedback (Greve, 2003).

Who learns in an organization? A multi-level (individual and collective learning) perspective of organizational learning has oriented research towards investigation of the combined mechanisms of the diverse tiers of learning. Sanchez (2005) proposes an interpretative framework of the transformation of individual learning in organizational learning through the intermediary of group (teams) learning. Wenger (1998) introduces the notion of community of practice; while Powell et al. (1996) analyse organizational learning from the networking perspective.

\section{Controversial perspectives on technology policy learning}

Several authors note the high concentration of research on private organizational learning and point out the need for closer investigation on the learning within the governmental sector (Moynihan and Landuyt, 2009).

\subsection{Public versus private organisational learning}

Crossan et al. (1999) recommends the study of organizational learning in public organizations as a key tool for improving both policy-making capacity and the delivery of public policies. Many scholars plead for careful investigation of the specifics of learning in the public sector (Busenberg, 2001; Getha-Taylor, 2008; Moynihan and Landuyt, 2009; Nutt, 2005). In their view, public organizations deal with greater complexity and ambiguity of the goals. Also differences in the organizational structure, the level of autonomy and accountability, the normative dimension, and work related attitudes and values are considered causes for important differences between organizational learning in public and private organizations. LaPalombara (2001) emphasizes the impact of power struggles that take place in public-sector organizations, which are described as risk-adverse and influenced by politics.

Meanwhile, other scholars dismiss the distinct traits of government organizations by considering them like public organizations from the private sector. They point out a tendency for priory considerations and oversimplifications that mark part of the accumulated knowledge about learning in public organizations (Rainey, 2009). According to Rainey and Bozeman (2000), the debate on this issue falls along two lines with some studies that consider differences between public and private organizations as a 
truism and others that treat these distinctions with contempt. By assessing a large number of studies spanning two decades, Rainey and Bozeman (2000) observed right and wrong points for both perspectives. Depending on the sector and type of organizational activity, private and public organization behaviour may sometimes converge, while others diverge greatly. Therefore, the authors called for deep and meticulous empirical analysis of public organizational learning to avoid the superficiality trap.

\subsection{Technology policy learning drivers, actors and content}

Two different theoretical stances have sustained the debate on the triggers of technology policy change. A first perspective is based on an institutional approach, while the second emphases learning as a source of change (Bennett and Howlett, 1992; Lieberman, 2002). According to the institutional approach, public policies changes are propelled by the social pressures and conflicts or by the public bureaucracies. The other perspective considers governmental learning as the main driver of the policymaking process. Hall (1993) describes public organizational learning as a deliberate, less conscious activity of government that revisits its own past experiences in order to adjust the goals of its policies, or to better respond to various environmental stimuli. Sabatier and Jenkin-Smith (1988) suggest that policy-oriented learning happen when, the results from the analysis of past and current policies are considered in the subsequent policymaking process. Finally, Rose (1991) has introduced the concept of lesson-drawing policy learning which is defined as the process of adoption from a country the programmes and policies developed from other countries. As cross-national policy diffusion often relies on international networks and policy communities to provide forums for interaction, the patterns of policy adoption by governments can be explained by analyzing mechanisms of policy dissemination as processes of organizational learning (Crossan et al., 1999).

The relationship among access to knowledge, processing time (and capacity) and the public policy decision-making has also nurtured various points of views. Stone (2001) categorize the decision-makers in several groups based on the criteria of their access to new knowledge and information and their importance on the decision-making process. High-level politicians (the political executives and legislators) have the primary role on the decision-making, but they do not have the time to access and consider detailed information. In addition, high-level politicians are more likely to view the policy-making process as a political activity. According to Stone (2001), another important faction is composed of civil servants and appointed officials, who are an elite group characterized by permanence, security, high standards, and promotion by merit and code of political neutrality. They are responsible for processing the information, synthesizing it, and briefing the high-level politicians. The street level bureaucrats and research editors and evaluators are supposed to gather the needed information, and to edit, prepare and synthesize the inputs that will be provided to the senior civil servants. Depending on each country's bureaucratic traditions, each of these decision-making levels will be more or less able to capture, explore, and exploit new knowledge in order to improve the decision-making process.

Bennett and Howlett (1992) suggest a broader view of the participating groups in the policy-decision making process. These authors combine the state officials group, the policy networks group, and the policy communities group. The policy networks include various levels of government personnel in policy formulation and implementation, as well as researchers, policy analysts, journalists who play important roles in the 
generation, dissemination, and evaluation of public policies [Sabatier and Jenkin-Smith, (1988), p.131]. The policy community group relates to the community of practice concept and has been introduced in the public organizational learning literature from Rose (1991). He suggests that elected officials searching for lessons prefer to turn to those whose overall political values are consistent with their own. Therefore, national or transnational epistemic communities are created and they become sources of new ideas. A careful examination of the learning capability of each decision-making group provides important insights into the causes of public policies successes and failures.

Is public policy learning a low or high-level type of learning? High-level organizational learning happens when the organizational members share the same understanding about the new knowledge and ideas and pursue the same goals in terms of transforming organizational values, culture, and operating processes. The multiplicity of participants in the decision-making process renders this sort of goal alignment difficult to attain in a democratic system context. In addition, double and third-loop learning should contribute to the achievement of organization's strategic objective. Or, in the case of public policy, the tendency to make decisions based on ideological standpoints prevails over theoretical and empirical evidence. Therefore, the policy environment is thought to not be propitious to double and third loop learning in public organizations (Common, 2004).

By revisiting, through stylized facts, the history of Canada's aircraft sector development, this study explores the interactive dynamics between the technology policy learning and an innovation system emergence and growth.

\section{The Canadian aircraft industry dynamics}

Canada has a small domestic market and relatively modest defence and space programmes. $78 \%$ of Canadian aircraft industry output is for civil use, as compared with $44 \%$ in the USA. Nonetheless, the country ranks 5 th in world aerospace sales and employment after USA, UK, France, and Germany, and ranks 3rd in world civil aircraft production after USA and France. Canada has attained world leadership in several industry sectors such as the regional and business aircraft sector $(47 \%$ of the world production); flight simulators $(70 \%)$, landing gears for large transport aircrafts $(60 \%)$, and environment control systems $(60 \%)$. What are the roots of excellence of the Canadian aircraft industry? This section retraces the dynamics of the Canadian aircraft industry catching up and identifies how public policy has affected these dynamics.

\subsection{Lagging behind: a self-organised system and erratic public initiatives}

The Canadian aircraft industry had a slow start. Two important waves characterized the emergence of the Canadian aircraft industry. They both represented private initiatives which gained importance during the world wars and faded immediately afterwards.

The first Canadian firm dedicated to the production of flying machines was Canadian Aerodrome, founded in 1909. It was a derivative of Aerial Experiment Association (AEA) whose founder was Alexander Graham Bell. Two flying machines were built but both crashed during the flying tests which in turn sealed the fate of the company. In 1915 , on the verge of WWI, the US company Curtiss-Wright established a subsidiary in Toronto. Its aim was to benefit from the military orders of both Canadian and British 
governments, but the Canadian Government created in 1916 its own experimental centre, the Canadian Aeroplanes. During the two following years, without surprise, Canadian Aeroplanes received most of the aircraft orders related to public procurement and produced 1,243 planes. The company was dissolved after the Armistice. Curtiss Aeroplanes \& Motors of Canada also ceased activity in 1919, after having produced only 30 planes. As shown in Table 1, some 20 Canadian companies tried to design and built planes between 1909 and 1920. Some 38 prototypes were built but could not reach technological and commercial success. The majority of these firms did not survive the first year of existence. Apart for the planes produced during 1917 and 1918 by Canadian Airplanes, only 63 planes were produced in Canada between 1909 and 1920. During the same period, 17,674 planes were built in the USA.

Table 1 Canadian aircraft constructors, 1909-1944

\begin{tabular}{|c|c|c|c|c|c|}
\hline \multirow{2}{*}{$\begin{array}{l}\text { Canadian aircraft } \\
\text { constructors, } \\
\text { 1909-1944 }\end{array}$} & \multicolumn{2}{|c|}{ Localisation } & \multirow{2}{*}{$\begin{array}{c}\text { Start of } \\
\text { production }\end{array}$} & \multirow{2}{*}{$\begin{array}{l}\text { End of } \\
\text { production }\end{array}$} & \multirow{2}{*}{$\begin{array}{l}\text { Number } \\
\text { of aircraft } \\
\text { produced }\end{array}$} \\
\hline & City & Province & & & \\
\hline Bell Laboratory & Beinn Bhreagh & New Scotland & 1909 & 1912 & \\
\hline Canadian Aerodrome & Halifax & New Scotland & 1909 & 1913 & 3 \\
\hline $\begin{array}{l}\text { Guaranty Iron } \\
\text { Works Aircraft }\end{array}$ & Winnipeg & Manitoba & 1910 & 1914 & 2 \\
\hline W.W. Gibson & Victoria & British Columbia & 1910 & 1911 & 2 \\
\hline P.H. Reid & Montreal & Quebec & 1911 & 1914 & 4 \\
\hline W.P.A. Straith & Winnipeg & Manitoba & 1911 & 1912 & 2 \\
\hline G. \& 'Ace' Pepper & Davidson & Saskatchewan & 1911 & 1911 & 1 \\
\hline $\begin{array}{l}\text { W.\&W Templeton } \\
\& \text { McMullen }\end{array}$ & Vancouver & British Columbia & 1911 & 1911 & 1 \\
\hline H.E. Clarke & Vancouver & British Columbia & 1912 & 1923 & 2 \\
\hline G. Pollien & Montreal & Quebec & 1912 & 1912 & 1 \\
\hline $\begin{array}{l}\text { Canadian } \\
\text { Aircraft Works }\end{array}$ & Montreal & Quebec & 1914 & 1914 & 2 \\
\hline Pollay Bros & Belleville & Ontario & 1914 & 1914 & 1 \\
\hline Curtiss & Toronto/Montreal & Ontario/Quebec & 1915 & 1919 & 30 \\
\hline J.\&H. Hoffar & Vancouver & British Columbia & 1915 & 1919 & 3 \\
\hline E.D. Bonisteel & Toronto & Ontario & 1915 & 1915 & 1 \\
\hline F. Kent & Vancouver & British Columbia & 1915 & 1915 & 1 \\
\hline R. McDowall & Owen Sound & Ontario & 1915 & 1915 & 1 \\
\hline Hamilton Aero & Vancouver & British Columbia & 1916 & 1916 & 1 \\
\hline Polson Iron Works & Toronto & Ontario & 1916 & 1916 & 1 \\
\hline Canadian Aeroplanes & Toronto & Ontario & 1917 & 1918 & 1,243 \\
\hline Ericson Aircraft & Toronto & Ontario & 1920 & 1926 & 37 \\
\hline Canadian Vickers & Montreal & Quebec & 1923 & 1944 & 532 \\
\hline J.V. Elliot & Toronto & Ontario & 1925 & 1927 & 7 \\
\hline Reid-Curtiss & Montreal & Quebec & 1928 & 1932 & 44 \\
\hline
\end{tabular}


Table 1 Canadian aircraft constructors, 1909-1944 (continued)

\begin{tabular}{|c|c|c|c|c|c|}
\hline \multirow{2}{*}{$\begin{array}{l}\text { Canadian aircraft } \\
\text { constructors, } \\
\text { 1909-1944 }\end{array}$} & \multicolumn{2}{|c|}{ Localisation } & \multirow{2}{*}{$\begin{array}{c}\text { Start of } \\
\text { production }\end{array}$} & \multirow{2}{*}{$\begin{array}{c}\text { End of } \\
\text { production }\end{array}$} & \multirow{2}{*}{$\begin{array}{l}\text { Number } \\
\text { of aircraft } \\
\text { produced }\end{array}$} \\
\hline & City & Province & & & \\
\hline Canadian Aircraft & Winnipeg & Manitoba & 1928 & 1928 & 1 \\
\hline Fleet Aircraft & Fort Erie & Ontario & 1930 & 1947 & 2,720 \\
\hline Fairchild Aircraft & Montreal & Quebec & 1930 & 1945 & 989 \\
\hline Boeing of Canada & Vancouver & British Columbia & 1930 & 1945 & 389 \\
\hline O\&W McVean & Chatham, Dresden & Ontario & 1930 & 1931 & 2 \\
\hline $\begin{array}{l}\text { G.W Saynor } \\
\text { \& R.N.Bell }\end{array}$ & Montreal & Quebec & 1930 & 1930 & 1 \\
\hline Noorduyn Aviation & Montreal & Quebec & 1935 & 1945 & 3,703 \\
\hline Opas & Toronto & Ontario & 1935 & 1937 & 4 \\
\hline $\begin{array}{l}\text { Canadian Car } \\
\& \text { Foundry }\end{array}$ & Hamilton/Montreal & Ontario/Quebec & 1938 & 1945 & 3,612 \\
\hline $\begin{array}{l}\text { De Havilland } \\
\text { of Canada }\end{array}$ & Toronto & Ontario & 1938 & 1947 & 2,600 \\
\hline National Steel \& Car & Toronto/Montreal & Ontario/Quebec & 1939 & 1943 & 961 \\
\hline Canadian Associated & $\begin{array}{c}\text { Toronto/Montreal/ } \\
\text { Winnipeg }\end{array}$ & $\begin{array}{c}\text { Ontario/Quebec/ } \\
\text { Manitoba }\end{array}$ & 1940 & 1942 & 160 \\
\hline Noury Aircraft & Hamilton & Ontario & 1940 & 1940 & 3 \\
\hline $\begin{array}{l}\text { McDonald Bros } \\
\text { Aircraft }\end{array}$ & Winnipeg & Manitoba & 1941 & 1945 & 1,067 \\
\hline $\begin{array}{l}\text { Ottawa Car \& } \\
\text { Aircraft }\end{array}$ & Ottawa & Ontario & 1941 & 1942 & 60 \\
\hline Federal Aircraft & Montreal & Quebec & 1941 & 1943 & 2 \\
\hline Victory Aircraft & Toronto & Ontario & 1943 & 1945 & 432 \\
\hline
\end{tabular}

Contrary to what happened to the USA, where the pioneers of the aircraft industry worked simultaneously to build their aircrafts and created a market for them, in Canada the success of air transportation preceded the domestic aircraft production activity. Canada's rapid adoption of aircraft as a means of transportation was accelerated by the large geographical distances separating dispersed populations, the lack of infrastructure connecting several corners of the country, as well as the concentration of most natural resources (forestry, copper and gold mines) in the country's Northern regions. By the end of WWI, most of southern Canada had been linked by railways, but the North remained as inaccessible as ever by land. Its innumerable lakes and rivers did, however, provide a landing place for water-based aircraft in summer and ski-equipped aircraft in winter. Laurentides Air Service was the first transporter, which formally started its activity in 1920. This Quebec company carried out air-mail, passenger, and freight services in Quebec and Ontario. Then, air transportation spread gradually in Ontario and in the Canadian western provinces. However, all the aircrafts circulating in the Canadian sky were bought or rented in the USA. 
Meanwhile, the Canadian military demand for aircraft was nonexistent. Compared to the other developed countries, the Canadian Government showed the least level of interest in the aircraft industry. This disinterest persisted even during the First World War. Finally in 1918, when a few German submarines approached the Nova Scotia's coasts, did the Canadian Government create the Royal Canadian Naval Air Force, equipped with British planes. In 1922, a government commission concluded that from the point of view of planes manufacturing, the country lagged far behind other countries. However, no concrete initiatives were undertaken to change this situation.

A second wave of solely private initiatives was accountable for the resurgence of the Canadian aircraft industry in the late 1920s. Some 20 firms carried on aircraft manufacturing activities. Some were subsidiaries of US and British companies. For instance, Fairchild Aircraft (1929), Boeing Aircraft of Canada (1929), Fleet Aircraft of Canada (1929) were subsidiaries of US companies. In 1927, because of its non-Canadian nationality, Fairchild was ruled out of the contracts for the Canadian airmail. To avoid this in the future, the company decided to create a subsidiary in Canada. Boeing acquired a shipbuilding manufacturer from Vancouver and used it as a subcontractor whenever the demand for hydroplanes exceeded Boeing's own Seattle-based production capacity. Therefore, the production of Boeing's Canadian site was intermittent. From 1932 to 1937 it didn't produce any aircraft. Fleet Aircraft also used its Canadian subsidiary to handle excessive demand. In 1934, the mother-company handed over to the Canadian subsidiary the production of 34 planes which were ordered by China.

Canadian companies such as Ottawa Car \& Aircraft (1927), MacDonald Bros Aircraft (1928), National Steel Car \& Victory Aircraft (1935), and Canadian Car \& Foundry (1936) also came into being during this second wave of aircraft firms' founding. Ottawa Car \& Aircraft (OCA) was initially engaged in distribution and service operations on behalf of Armstrong Siddeley (GB) and Consolidated (US) and then upgraded its technological capabilities and became a subcontractor for Armstrong Siddeley, Consolidated, and other aircraft companies. Furthermore, Reid \& Curtiss-Reid Aircraft and Noorduyn Aircraft were two notable spin-offs firms. Thomas Reid left Canadian Vickers and launched his own firm in 1928. In 1934, Robert Noorduyn decided to start his own company in Montreal, Quebec. He had worked for several years for the US subsidiary of the Dutch company Fokker as well as for the US company Bellanca. Montreal's primary attributes were availability of capital and favorable geographical location. Noorduyn became one of the most eminent airframe manufacturers of the Canadian aircraft industry, while Thomas Reid's firm went bankrupt in 1932 due to the Great Depression.

Government's role during this period remained modest and was mostly focused on attracting foreign investments in this sector. In 1928, by opening the door of potential access to public procurement, the Canadian Government convinced the British company De Havilland to invest in a Canadian subsidiary. Also, a few years before then, determined to stimulate Canadian naval construction, the government had solicited several British shipbuilding manufacturers to invest in Canada. One of them, Vickers Co., responded positively by establishing a division in Canada in order to benefit from aircraft orders from the Royal Canadian Navy. In 1923, Canadian Vickers entered into the aircraft manufacturing business and won a contract to supply Vickers Viking flying boats to the recently formed Canadian Air Force. Table 2 summarises the factors that determined the location of aircraft firms during this emergent period. 
Table 2 Canadian industry location factors

\begin{tabular}{lcc}
\hline Location factors & City & Company name \\
\hline Path dependence & Montreal; Toronto; & Canadian Car \& Foundry/National Steel \\
& Vancouver; Winnipeg & $\begin{array}{c}\text { Car \& Victory Aircraft/Boeing/Aircraft } \\
\text { of Canada/McDonald Bros Aircraft }\end{array}$ \\
Geographic proximity & Fort Erie/ & Fleet Aircraft of Canada/Boeing/ \\
& Vancouver/Toronto & Aircraft of Canada/Curtiss Aeroplanes \\
Proximity to investors & Montreal & Noorduyn Aircraft/ \\
Favorable site conditions & Montreal/Toronto & Fairchild Aircraft/De Havilland of Canada \\
Government decision & Winnipeg & McDonald Bros Aircraft \\
Spin-off & Montreal & Reid \& Curtiss-Reid Aircraft \\
Historical accident & Montreal & Canadian Vickers \\
\hline
\end{tabular}

Table 3 The origin of Canadian aircraft designs

\begin{tabular}{|c|c|c|c|c|}
\hline Aircraft manufacturer & Aircraft model & $\begin{array}{l}\text { Number } \\
\text { of aircraft } \\
\text { produced }\end{array}$ & $\begin{array}{l}\text { Aircraft designer } \\
\text { company }\end{array}$ & $\begin{array}{c}\text { Country of } \\
\text { origin of } \\
\text { aircraft designs }\end{array}$ \\
\hline Nooduyn Aircraft & Harvard IIB & 2,800 & North America & USA \\
\hline Fleet Aircraft & PT-26 Cornell & 1,642 & Fleet & USA \\
\hline De Havilland of Canada & DHC 2 Beaver I & 1,631 & De Havilland & UK \\
\hline Canadian Car \& Foundry & Hawker Hurricane & 1,451 & $\begin{array}{c}\text { Hawker Aircraft } \\
\text { Hurricane }\end{array}$ & UK \\
\hline Canadian Aeroplanes & JN-4 (Canadian) & 1,210 & Curtiss & USA \\
\hline Canadian Car \& Foundry & SBW Helldriver & 835 & Curtiss & USA \\
\hline $\begin{array}{l}\text { Nooduyn Aircraft/ } \\
\text { Aviation }\end{array}$ & Norseman VI & 756 & $\begin{array}{l}\text { Aircraft/ } \\
\text { Aviation }\end{array}$ & Canada \\
\hline MacDonald Bros Aircraft & 652A Anson $\mathrm{V}$ & 748 & Avro & UK \\
\hline National Steel Car & 652A Anson II & 736 & Avro & UK \\
\hline Fleet Aircraft & 16 & 435 & Fleet & USA \\
\hline Victory Aircraft & 683 Lancaster X & 422 & Avro & UK \\
\hline Fairchild Aircraft & Bolingbroke IVT & 407 & Bristol & UK \\
\hline De Havilland of Canada & $\begin{array}{c}\text { D.H.98 } \\
\text { Mosquito B.25 }\end{array}$ & 400 & De Havilland & UK \\
\hline De Havilland of Canada & $\begin{array}{c}\text { DHC DHC-6 } \\
\text { Twin Otter } 300\end{array}$ & 380 & De Havilland & UK \\
\hline
\end{tabular}

Source: $\quad$ Prepared from data shown in Molson and Taylor (1982).

Canadian Aircraft since 1909.

Great Britain: Canada's Wings Inc.

From 1940 to 1944, Canadian aircraft manufacturers contributed greatly to the WWII efforts by producing some 15649 aircraft. The scale and scope of the war efforts endowed Canadian aircraft firms with state-of-the-art aircraft technologies. As shown in Table 3, the Canadian planes were produced under license from British and US models. Only one out of 12 aircraft models built in Canada was based on an indigenous design. 
As Todd and Simpson (1986) stated, Canadian industry was then appendix of the US and British aircraft industries. The pre-war inability to create indigenous aircraft models indicates the low level of technical and organizational capabilities of Canadian aircraft manufactures. The Canadian Government followed a path that was much less ambitious than the other developed countries (USA, UK, France, Germany) which showed more interest and offered more support to the newly formed aircraft industry. However, during WWII, Canada's aircraft manufacturers experienced an accelerated learning curve and expanded their activity far beyond the levels that would have been possible by following the pre-war rhythm of growth.

During the emergence of the aircraft sector, technology policy learning was an erratic process. Public intervention was of a little impact on the industry emergence dynamics. History accidents (the two world wars) were the major drivers of the embryonic public policies concerning the nascent aircraft industry. The sporadic and quite intuitive interventions carried on during this first period, demonstrates a low level of technology policy learning.

\subsection{Forging ahead: the aircraft industry under the government wing}

Despite its modest beginnings and without a strong military aircraft sector, the Canadian aerospace industry became one of the world's best. What are the modalities and features of this successful 'catching up'? Government technology policy became the main determinant factor of this process. Following the path of other developed countries, Canada moved from a traditional conception of the industrial policy according to which government's main role is to provide the basic economic infrastructures, toward technology policy where government plays an active role in promoting industrial development (Niosi, 2005, 2010). Starting in the mid-1950s, still a new and fledgling industry, Canadian aerospace will henceforth be considered a highly strategic industry from the point of view of both national security and the promotion of the technological progress of the country. Thus, from a sporadic contributor, the Canadian Government became the principal determinant of the post war growth of the Canadian aircraft industry.

The catching up of the Canadian aircraft industry was a long and gradual process. Aiming to constitute a solid Canadian presence in the growing and promising civil aviation sector, at the end of the WWII and after the complete collapse of military demand, the Canadian Government protected and subsidized the aircraft industry. In this context, the first crucial intervention by the government was to secure strategic investments to the industry but by targeting in the same time only a few winners. In terms of selection, government choices reflected a recently learned lesson. During the war, due to the shortage of airplanes, the USA and UK denied Canada's requests for military aircraft, even during the time that the Japanese army was seriously threatening the Canadian West Coast. After being denied the purchase of Hawker Hurricanes that were being produced in Fort William, Ontario, the Canadian Government realized the importance of developing an independent aircraft industry (Molson and Taylor, 1982). Learning from its own experiences became a principal driver of public policy change with respect to a growing aircraft sector.

In 1944, Canadian Vickers decided to reorient its activity by focusing solely on shipbuilding and withdrew from the aircraft sector. The government acquired the Canadian Vickers aircraft division and founded Canadair whose first mandate was the 
conversion of a few thousand military aircraft to civilian use. At the same time, Ottawa bought from Douglas Co. the license of the C-54/DC-4. With these successful acquisitions, Canadair produced its first commercial success, the North Star, and monopolized the orders from Royal Canadian Air Force, Trans-Canada Airlines, and Canadian Pacific Airlines. In 1947, now well on track, Canadair was acquired by the Electric Boat Company, which in 1952 became General Dynamics. The privatization of government-owned companies was forced primarily by Clarence Decatur Howe, then the Canadian Minister of Transports, whose objective was to maintain a viable Canadian aircraft industry. Minister Howe was a central figure in shaping the future of the Canadian aircraft industry. His personal involvement went as far as bringing a former vice-president of Boeing, H. Oliver West, to be the head of Canadair, West's most remarkable contribution was the transformation of Canadair ton a Tier 1, system assembling company. De Havilland was the other aircraft manufacturer that received strong public support. Also, in 1945, after three years of negotiations, the Canadian Government attracted to Toronto a subsidiary of the British airframe manufacturer A.V. Roe. At this stage of the aircraft industry life cycle a single person could play a crucial role in industry restructuring and growth. The still embryonic sectoral innovation system was very dependent on individual learning and absorptive capacity of the highest level of decision makers.

After being excluded by this 'select club' of firms receiving public support, several airframe manufacturers closed their doors. Examples included Noorduyn Aviation (ended the activity in 1945), Boeing Aircraft of Canada (ended the activity in 1945), Ottawa Car \& Aircraft (1947), and Fairchild Aircraft (1948). Canadian Car \& Foundry (CCF), which was the second largest airframe manufacturer in Canada at the end of the WWII, tried to survive by drastically reducing its activities. In the years following War, the company's facilities downsized from 1,700,000 to only 157,930 square feet. In 1955, CCF was acquired by Avro. Fleet adjusted by downgrading its activity and becoming a supplier for Canadair, Avro, and Republic. MacDonald Bros tried to find a niche in the armament sector.

The after War winners - targeting public procurement and subsidies shaped the future of the Canadian aircraft industry. In the next decade, Canadair, Avro, and De Havilland controlled $84 \%$ of overall Canadian aircraft production. This level of consolidation was common to all the aerospace countries. However, the limited aircraft market and the companies' lack of resources accelerated the rationalization and concentration of the Canadian industry.

Parallel to the efforts of supporting national champions, the Canadian Government invested for the development of diversified and multidisciplinary $R \& D$ infrastructure. Created in 1916, the National Research Council (NRC) became after the WWII a multidisciplinary network of public institutions that helped the aircraft industry transform into a leader in aerospace innovation Also during this time, the government strongly supported the ambitious innovation projects of private companies. For instance, in the case of the Jetliner project of Avro, public financial participation increased to $75 \%$ of overall R\&D expenditures.

The third major aspect of public intervention in developing the Canadian aircraft industry was the successful integration of the industry within the US market. In 1957, Canada and the USA signed the North American Air Defense Agreement (NORAD) which stipulated the creation of a bi-national defence command. One of the positive consequences of this agreement was full access of Canadian companies to the US market, 
including the US defence-related public procurement. This was of great importance because the 'Buy American Act', made the US market impenetrable to foreign firms. Since the long years of the Vietnam conflict, Canadian aircraft companies have directed almost all of their exports towards the US military market (Todd and Simpson, 1986). The growing complexity of the aircraft industry was followed by the ramification of government policies in many complementary ways aimed at supporting this sector. Actors, from both private and public sector, engaged in a trial and error process of policy building. Compared to the emerging stage of the aircraft industry, the main change during the industry growth period was the driver of public policy learning. Totally absent during the first stage, the Canadian aerospace developing strategy was an indispensable framework for rapid learning for both private and public actors.

However, the aircraft industry is known for cyclic growth, and if the Canadian aircraft industry benefited during the rapid expansion of the US demand, it also paid a high price during the period of stagnation or contraction. This was the case in the mid 1970s. Following the drastic reduction in US demand of the Canadian aircraft industry, employment decreased from 48.000 to 25.000 in 1976 (Todd and Simpson, 1986).

This downsizing period in the aircraft industry coincided with the introduction of the Canadian Government's national strategy for diversifying the productive structure in order to reduce dependence on natural resources. The aircraft industry remained in the group of industries considered as essential vectors for Canadian technological development. This ensured long term and solid public support of the Aircraft industry. The government's determination to drive the aircraft industry toward the best international standards was made clear in 1974. When the British group Hawker Siddeley decided to shut down the DHC Dash 7 programme at its Canadian subsidiary De Havilland, the Canadian Government nationalized the company and financed the rest of the project. This avoided the potential risk of downgrading the airframe manufacturer to an outsourcing company.

At the same time, Canadair was also going through a very difficult period. The company's efforts to diversify were not successful. The industry's downturn in the mid 1970s caused Canadair to reduce its workforce from 9,250 to 2,000 (Pickler and Milberry, 1995). In 1976, in order to prevent the company's loss, the federal government acquired Canadair for the second time in 20 years.

The analysis of this period emphasizes a successful combination of private and public efforts which helped the Canadian aircraft industry to overcome the world recession. While De Havilland kept working on the Dash 7 programme, Canadair launched the Challenger project. The infallible public support helped the two manufacturers to face innumerable technical, financial or organizational uncertainties and risks inherent to their ambitious innovation projects.

In the mean time, the government wisely used its trade and foreign investment policy to obtain from the US partners considerable offsets which involved strategic outsourcing such as technology transfer or components that went far beyond what would normally have been assumed to be commercially necessary (Mowery, 1983). Canada was the foreign country that received the largest offsets from US public or private sector companies. Furthermore, by offering different types of incentives, the Canadian Government was the main force behind the decision of world's aircraft industry leaders to invest in Canada. Public incentives are the main explanation of the De Havilland 
(1928), Pratt and Whitney (1928), Avro (1945), and Bell Helicopter Textron (1984) decisions to establish their respective Canadian subsidiaries.

\subsection{The challenges of maturity phase: from 'catching up' to 'keeping up' technological policies}

After the privatization in the 1980s of the aircraft industry, government remained a key actor. However, its role and modalities of supporting the industry have changed radically. Without becoming a passive protector of the aircraft industry, government distanced itself from the industry strategic decisions which were thereafter the prerogative of the system integrators. For instance, the decisions of Bombardier to acquire the Irish Short Brothers (in 1989), the American Learjet (in 1990) or De Havilland (in 1992) was a result of the company's strategic vision of becoming the world leader in the business and regional aircraft niche. In a context of growing international competition, attaining this objective would have not been possible without the persistent support of both federal and provincial governments.

Furthermore, significant industry reorganization occurred by the end of the 1970s. The increasing product complexity, the explosion of the R\&D expenditures, and the persistent pressure of the budgetary constraints forced the main aircraft manufacturers to focus their activity toward the core competences or the sources of their competitive advantage. The aircraft is an assembly of interdependent subsystems that are designed to perform a particular function. This highly modular architecture of aircraft was very favourable to the industry's reorganization. A three-level hierarchical industrial structure emerged with the top (Tier 1) being the system integrators or the prime contractors which are in charge of the design, development, and final assembling of aircraft. In the second level (Tier 2), there are original equipment manufacturers (OEM) or the subsystems suppliers which are responsible for the assembling of the main aircraft subsystems (for instance, avionics, airframe systems or power plants). At the bottom (Tier 3), there are the subcontractors who offer specific components or services.

The reconfiguration of the inter-firms' relationships had a double effect on the regional and national airspace innovation systems. On one hand, the new hierarchical organization of the aircraft industry was followed by an increasing geographical clustering of the firms. The presence in a region of one or a few prime, tier I aircraft contractors exerted a powerful attraction of Tier 2 and Tier 3 firms. This was the case of the Montreal aerospace cluster, where the presence of Bombardier, Bell Helicopter, and Pratt and Whitney attracted a considerable number of other aerospace related firms. In 1970, there were some 50 firms in the Montreal' airspace sector. They were 100 firms in 1985, while presently, the Montreal aerospace cluster counts some 250 firms.

On the other hand, the new hierarchical industry configuration transformed the relationships among the firms. In the traditional context, the interactions were sporadic, of short duration, and driven mostly by the market, the price being the principal criterion of choice of the subcontractor (Bourgault et al., 1994). In this new context, relationships were longer term and indicated proactive exchanges among the partners. The prime contractors drove the system toward higher quality standards and the sub-system assemblers and, to a lesser degree, the subcontractors participated in the prime contractors' innovation efforts (Bourgault et al., 1994). 
Universities and public $R \& D$ laboratories have also multiplied the links with the industry. Attentive to the industry needs, the Canadian Government has continuously upgraded the public R\&D infrastructure with specialized laboratories or national agencies (for example the Canadian space agency). By combining horizontal and vertical policy programmes, government has evolved from a few intensive partnerships with the major aircraft industry firms toward a more SME inclusive programmes.

Universities role also has progressively grown by transforming their role from centres for preparing a highly skilled labour supply toward active industry partnerships in innovation projects. Conversely from other knowledge intensives sectors, where research universities are a major source of knowledge spillovers and many spin-off firms are created, in the case of the aircraft industry, it is the private sector that has taken the lead of $R \& D$ and launched many initiatives involving universities in research projects.

Since its beginnings, the aerospace industry has been global in terms of market. Furthermore, since the 1980s, its supply chain has also become increasingly international. In search of foreign governments subsidies and access to markets, risksharing collaborations, and lower production costs, system integrators have established a close international network. Presently, system integrators have engaged in an active supply chain transforming process intended to reduce the number of suppliers by going from one-to-many to one-to-few relationships. The high degree of activity concentration that characterized the Tier 1 and Tier 2 levels of the industry reduces the choice of OEM (subsystem integrators) and increasingly orients the prime contractors toward the international supply chain. For instance, only $18 \%$ of Bombardier's suppliers are Canadian firms.

Several authors have noticed that the acceleration of the globalization process of the aerospace industry is increasingly disrupting the traditional interaction of local actors and is redefining the role of national governments (Bélis-Bergouignan et al., 2001; Iaurif, 2005; Frigant and Talbot, 2003). The same phenomenon is observed in the case of Canadian aircraft innovation systems which calls for policies able to reinvent the relationships between the local actors. The ability to stimulate the upgrading process of the Tier II firms in subsystem integrators has become a great challenge for policymakers.

In this context, the growth and maturity stage of the aircraft industry is characterized by far more complex dynamics compared to the emergence period. The number and type of actors, and as a result, the decision-making centres are more diversified and dispersed, which directly affects the efficacy of the top-down type of public policy. Table 4 represents the dynamics of supporting public policies throughout the Canadian aircraft innovation system, that is the emerging, growing and maturity stages.

This stylized history of Canadian aerospace sectoral innovation system building proves that public policy learning and change results from the interaction of institutional and organizational drivers. Public policy learning and private organization learning processes share some common features although also displaying idiosyncrasies. In one hand, learning process of both private and public actors has shown strong dependence on their absorptive capacity. They both have evolved from an intuitive type of learning toward an institutionalized one. In another hand, the pace and direction of public policy learning have been less rapid and more ambiguous than those experienced in the private sector. Furthermore, private actors were the main engine during the industry emergence period while government became a keystone during the industry growth stage. 
Table 4 Some Canadian technology policy supporting tools to the aerospace industry

\begin{tabular}{|c|c|c|c|}
\hline \multirow{2}{*}{$\begin{array}{l}\text { Aerospace public } \\
\text { support } \\
\text { mechanisms }\end{array}$} & \multicolumn{3}{|c|}{ Canadian aerospace sectoral innovation system life cycle } \\
\hline & Emergence & Growth & Maturity \\
\hline $\begin{array}{l}\text { Financing R\&D } \\
\text { programmes in } \\
\text { public } \\
\text { laboratories and } \\
\text { universities }\end{array}$ & $\begin{array}{l}\text { National Research } \\
\text { Council Industrial } \\
\text { Research } \\
\text { Assistance } \\
\text { Program (NRC- } \\
\text { IRAP) (technical } \\
\text { information } \\
\text { advisors were } \\
\text { started in } 1945 \\
\text { under the } \\
\text { Department of } \\
\text { Reconstruction and } \\
\text { Supply (DORS) }\end{array}$ & $\begin{array}{l}\text { NRC Aerospace } \\
\text { (launched in } 1951 \text { as } \\
\text { National Aeronautical } \\
\text { Establishment (NAE). } \\
\text { Renamed the Institute for } \\
\text { Aerospace Research } \\
\text { (IAR) (also called NRC } \\
\text { Aerospace) in 1990. } \\
\text { Natural Science and } \\
\text { Engineering Research } \\
\text { Council of Canada } \\
\text { (NSERC). (Came into } \\
\text { existence in 1978. } \\
\text { University-based } \\
\text { research had previously } \\
\text { been supported through } \\
\text { the National Research } \\
\text { Council) }\end{array}$ & $\begin{array}{l}\text { The Strategic } \\
\text { Aerospace and Defence } \\
\text { Initiative (SADI) } \\
\text { (launched in 2007) }\end{array}$ \\
\hline Fiscal incentive & $\begin{array}{l}\text { At the federal } \\
\text { level, Canada has } \\
\text { provided tax } \\
\text { assistance since } \\
1944 .\end{array}$ & Continuing & $\begin{array}{l}\text { Since } 1985 \text { the } \\
\text { Scientific Research and } \\
\text { Experimental } \\
\text { Development tax credit. } \\
\text { Canada offers one of } \\
\text { the most favourable tax } \\
\text { treatments for R\&D } \\
\text { among the G-7 } \\
\text { members. }\end{array}$ \\
\hline $\begin{array}{l}\text { Direct and } \\
\text { indirect subsidies }\end{array}$ & & $\begin{array}{l}\text { Industrial and Regional } \\
\text { Benefits Program (IRB) } \\
\text { (launched in 1975) }\end{array}$ & $\begin{array}{l}\text { Funding technology } \\
\text { development through } \\
\text { Technology } \\
\text { Partnerships Canada } \\
\text { (TPC) (launched in } \\
\text { 1996). }\end{array}$ \\
\hline & & & $\begin{array}{l}\text { The Strategic } \\
\text { Aerospace and Defence } \\
\text { Initiative (SADI) } \\
\text { (launched in 2007) }\end{array}$ \\
\hline $\begin{array}{l}\text { Collaboration } \\
\text { enhancing } \\
\text { initiatives }\end{array}$ & & & $\begin{array}{l}\text { Office of Collaborative } \\
\text { Technology } \\
\text { Development, a } \\
\text { public/private sector } \\
\text { partnership (established } \\
\text { in 1999) }\end{array}$ \\
\hline & & & Technology roadmaps \\
\hline
\end{tabular}




\section{Conclusions}

The Canadian aerospace industry 'catching up' was a long and complex process. According to an evolutionary reasoning, chances for a technological policy to be perfect at once are minimal. Benchmarking, learning by doing, and trial and error policies have been a key factor of the level of excellence obtained by the Canadian aircraft industry. Government was the driving force during the growth phase of the industry. Public support was central to all aircraft development initiatives. Many of them failed to deliver a successful model. However, each of them contributed actively to the national knowledge base and competence accumulation which were transformed into commercial successes in later programmes. This is the case, for instance of Challenger 600, which was a commercial failure with only 83 aircraft sold. Yet, this programme was the basis of a successful business aircraft venture launched by Bombardier a few years later. Also Bombardier's CRJ aircraft programme, still the most important commercial success in terms of civil aviation (1,500 aircraft sold), was based on the Canadair CL601RJ programme that was developed when Canadair was a public organization. Many other examples indicate that Canada has been able to benefit by knowledge externalities. The analysis of the 'catching up' of the Canadian aircraft industry shows that proactive learning followed by continuous policy adjustments were the keys to avoid a lock-in situation and improvement in national and regional innovation systems performance.

However, the issue of how radically new knowledge is produced, and redefines 'best practice' as radical innovations are created, is left largely unexplored and merits further investigation. Only a few countries have successfully learned and have been able to make the change from one development trajectory to another. But many others continue to be unable to break their path dependences. The organizational learning perspective provides insightful elements towards an answer. Successful learning is bound by a conception of learning as a process rather than as an output (which is mostly the case). Also, learning and its output may be desynchronized in time and in space, so organizations should adopt a constant learning attitude.

\section{References}

Argyris, C. (2005) 'Double-loop learning in organizations: a theory of acton perspective', in Smith, K.G. and Hitt, M.A. (Eds.): Great Minds in Management: The Process of Theory Development, p.261-279, Oxford University Press, Oxford, Toronto.

Arrow, K.J. (1962) 'The economic implications of learning by doing', The Review of Economic Studies, Vol. 29, No. 3, pp.155-173.

Auluck, R. (2002) 'Benchmarking: a tool for facilitating organizational learning?', Public Administration and Development, Vol. 22, No. 2, pp.109-122.

Bélis-Bergouignan, M-C., Frigant, V. and Talbot, D. (2001) 'L'articulation global/local des modèles industriels pharmaceutique, automobile et aéronautique', Notes de recherche no.2001-6, Equipe Industries Innovation Institutions, Université Bordeaux IV.

Bennett, C.J. and Howlett, M. (1992) 'The lessons of learning: reconciling theories of policy learning and policy change', Policy Sciences, Vol. 25, No. 3, pp.275-294.

Bourgault, M., Lefebvre, L.A. and Lefebvre, E. (1994) 'Critical capabilities and performance of the small subcontracting firms in the aerospace industry', Serie scientifique no. $94 \mathrm{~s}$, Cirano.

Busenberg, G.J. (2001) 'Learning in organizations and public policy', Journal of Public Policy, Vol. 21, No. 2, pp.173-189. 
Castaldi, C., Cimoli, M., Nelson, C. and Dosi, G. (2009) 'Technological learning, policy regimes and growth: the long-term patterns and some specificities of a 'globalized' economy', in Cimoli, M., Dosi, G. and J. Stiglitz (Eds.): Industrial Policy and Development: The Political Economy of Capabilities Accumulation, pp.39-78, Oxford University Press, Oxford.

Cohen W.M. and Levinthal, D.A. (1989) 'Innovation and learning: the two faces of R\&D', The Economic Journal, Vol. 99, No. 397, pp.569-596.

Common, R. (2004) 'Organisational learning in a political environment: improving policy-making in UK Government', Policy Studies, Vol. 25, No. 1, pp.35-49.

Crossan, M.M., Lane, H.W. and White, R.E. (1999) 'An organizational learning framework: from intuition to institution', Academy of Management Review, Vol. 24, No. 3, pp.522-537.

Fiol, M.C. and Lyles, M.A. (1985) 'Organizational learning', Academy of Management Review, Vol. 10, No. 4, pp.803-813.

Frigant, V. and Talbot, D. (2003) 'Convergence et diversité au passage à la production modulaire dans l'aéronautique et l'automobile en Europe', Présenté à la 135ème journée de travail du GERPISA, MSH-EHESS, Paris, février.

Getha-Taylor, H. (2008) 'Learning indicators and collaborative capacity: applying action learning principles to the US Department of Homeland Security', Public Administration Quarterly, Vol. 32, No. 2, pp.125-147.

Greve, H.R. (2003) Organizational Learning from Performance Feedback. A Behaviooral Perspective on Innovation and Change, Cambridge University Press, Cambridge.

Hall, P.A. (1993) 'Policy paradigms, social learning and the state: the case of economic policymaking in Britain', Comparative Politics, Vol. 25, No. 3, pp.275-296.

Iaurif, T.P. (2005) La filière industrielle aérospatiale en Ile de France: état des lieux et enjeux, Institut d'aménagement et d'urbanisme de la région d'Ile de France, Paris.

Johnson, B. (1992) 'Institutional learning', in B-Å. Lundvall (Ed.): National Systems of Innovation: Towards a Theory of Innovation and Interactive Learning, pp.23-44, Pinter, London.

Lane, P.J., Koka, B.R. and Pathak, S. (2006) 'The reification of absorptive capacity: a critical review and rejuvenation of the construct', Academy of Management Review, Vol. 31, No. 4, pp.833-863.

LaPalombara, J. (2001) 'Power and politics in organizations: public and private sector comparison', in Dierkes, M. et al. (Eds.): Handbook of Organizational Learning and Knowledge, pp.557-581, Oxford University Press, Oxford.

Lieberman, R.C. (2002) 'Ideas, institutions, and political order: explaining political change', The American Political Science Review, Vol. 96, No. 4, pp.697-712.

Lundvall, B.A. (Ed.) (2010) National Systems of Innovation: Toward a Theory of Innovation and Interactive Learning, Anathem Press, London.

Lundvall, B-A., Johnson, B., Andersen, E.S. and Dalum, B. (2002) 'National systems of production, innovation and competence building', Research Policy, Vol. 31, No. 2, pp.213-231.

Molson, K.M. and Taylor, H.A. (1982) Canadian Aircraft since 1909, Canada's Wings Inc., Great Britain.

Mowery, D.C. (1983) 'Economic theory and government technology policy', Policy Sciences, Vol. 16, No. 1, pp.27-43.

Moynihan, D.P. and Landuyt, N. (2009) 'How do public organizations learn? Bridging structural and cultural divides', Public Administration Review, Vol. 69, No. 6, pp.1097-1105.

Niosi, J. (2005) Canada's Regional Innovation System: The Science-based Industries, McGillQueen's University Press, Montreal.

Niosi, J. (2010) Building National and Regional Innovation Systems. Institutions for Economic Development, Edward Elgard Publishing, Cheltenham.

Nutt, P.C. (2005) 'Comparing public and private sector decision-making practices', Journal of Public Administration Research and Theory, Vol. 16, No. 2, pp.289-318. 
Pickler, R. and Milberry, L. (1995) Canadair: The First 50 Years, CANAV Books, Toronto.

Powell, W.W., Koput, K.W. and Smith-Doerr, L. (1996) 'Interorganizational collaboration and the locus of innovation: networks of learning in biotechnology', Administrative Science Quarterly, Vol. 41, No. 1, pp.116-145.

Rainey, G.H. and Bozeman, B. (2000) 'Comparing public and private organizations: empirical research and the power of the a priori', Journal of Public Administration Research and Theory, Vol. 10, No. 2, pp.447-470.

Rainey, H.G. (2009) Understanding and Managing Public Organizations, Jossey-Bass, San Francisco, California.

Rose, R. (1991) 'What is lesson-drawing?', Journal of Public Policy, Vol. 11, No. 1, pp.3-30.

Rosenberg, N. (1982) Inside the Black Box. Technology and Economics, Cambridge University Press, Cambridge.

Sabatier, P. and Jenkin-Smith, H. (Eds.) (1988) 'Special issue: policy change and policy-oriented learning: exploring an advocacy coalition framework', Policy Sciences, Vol. 21, Nos. 2/3, pp.123-278.

Sanchez, R. (2005) 'Personal knowledge versus organizational knowledge approaches to knowledge management practice', in Rooney, D., Hearn, G. and Ninan, A. (Eds.): The Knowledge Economy Handbook, Routledge, Oxford.

Stone, D. (2001) Policy Paradox: The Art of Political Decision-making, W.W. Norton \& Co., New York.

Todd, D. and Simpson, J. (1986) The World Aircraft Industry, Croom Helm, London and Dover, Mass.

Van den Bosch, F., Van Wijk, R. and Volberda, H.W. (2003) 'Absorptive capacity: antecedents, models and outcomes', in Easterby-Smith and Lyles (Eds.:) The Handbook of Organizational Learning and Knowledge Management, pp.278-302, Blackwell Publishing, MA, USA, Oxford, UK.

Wenger, E. (1998) 'Communities of practice: learning, meaning, and identity', Cambridge University Press, Cambridge.

Zahra, S.A. and George, G. (2002) 'Absorptive capacity: a review, reconceptualization, and extension', Academy of Management Review, Vol. 27, No. 2, pp.185-203. 